AUTHOR:

S. Cruywagen

AFFILIATION:

University of Pretoria, Department of Music

CORRESPONDENCE TO:

S. Cruywagen

POSTAL ADDRESS:

152 Leonie Street, Doringkloof, Centurion, 0157

DATES:

Published: 21 Aug 2018

HOW TO CITE THIS ARTICLE: Cruywagen, S. , 2018. "Flourishing with music": from music students to well-rounded musicians of the 21st century. KOERS - Bulletin for Christian Scholarship, 83(1)

Available at: https://doi.org/10.19108/ KOERS.83.1.2306

COPYRIGHT:

(c) 2018. The Author(s)

Published under the Creative

Commons Attribution License.

\section{"Flourishing with music": from music students to well-rounded musicians of the $21^{\text {st }}$ century}

\begin{abstract}
People need music to sing, dance, play, work and listen to during a substantial part of their daily lives. Musicians understand and communicate life through music, a form of art that individuals and societies treasure. Tertiary music educators invest time and energy in order to assist music students in creating their own successful careers, but do their teaching and learning include holistic education approaches that develop the student into a well-rounded person? As a "think piece", this article advocates a few important perspectives that will encourage undergraduate music educators to structure a music programme that will prepare music students to flourish in their lives and future work place. 21st-century skills for living and lifelong learning recommended by researchers, business leaders and education specialists are acknowledged and related to the challenges of teaching music as a well-rounded person. Wellbeing, flow and mindfulness are aspects that open up other dimensions such as meaningfulness and spirituality.
\end{abstract}

Key concepts: Flourishing in music, well-rounded musicianship, $2^{1 s t}$ century skills, importance of well-being and spirituality in music, holistic education in music

\section{Opsomming}

Musiek speel hi belangrike rol in mense se alledaagse lewe. Hulle sing, dans op die maat van musiek, luister daarna wanneer hulle werk, kuier en sport beoefen. Musikante verstaan en kommunikeer die lewe deur musiek sodat individue en die samelewing dit as h kunsvorm kan ervaar en koester. Tersiêre musiekopvoeders spandeer tyd en energie om musiekstudente vir produktiewe betekenisvolle musiekloopbane voor te berei. Maar word daar ooit aandag gegee aan holistiese onderrig en leer wat musiekstudente se menswees ook aanraak en afrond? In hierdie artikel beredeneer ek h paar standpunte wat tersiêre musiekopvoeders sal aanmoedig om voorgraadse musiekkursusse so te struktureer dat musiekstudente in hul lewens en werkplek sal floreer. Ek ondersoek lewenslange leervaardighede wat deur sakeleiers, navorsers en onderrigdeskundiges a anbeveel word. Hierdie vaardighede word verbind met die uitdagings om musiekstudente te laat fokus op hul persoonlike welstand, die hier-en-nou, betekenisvolle lewe en hul verbintenis met spiritualiteit deur musiek en musiekaktiwiteite.

Kernbegrippe: 'n Positiewe lewenshouding deur musiek, afgeronde menswees, 21ste eeu vaardighede, waarde van persoonlike welstand en spiritualiteit in musiek, holistiese musiekonderrig en leer. 


\section{Prelude}

Oh, you gotta get a glory

In the work you do;

A hallelujah chorus

In the heart of you.

Paint, or tell a story,

Sing, or shovel coal,

But you gotta get a glory

Or the job lacks soul. ${ }^{1}$

Undergraduate music students can choose various career options to specialise in. At several tertiary institutions in South Africa music students are given the opportunity to choose a variety of courses from their respective music programmes to become composers, performers, musicologists, ethnomusicologists, music educators or music therapists. As music entrepreneurs they may also prefer to become part of the music recording and production environment. Choosing music as a profession is a humane calling which has always influenced the progression of humanity and shaped individuals and communities. Music tells stories about people, portrays the way the world is viewed, distinguishes cultures and plays a fundamental part in education. It is therefore essential that tertiary music programmes not only teach students to become career professionals who retransmit knowledge and skills, but that they also produce musicians and music teachers who "flourish" as human beings. Music programmes should guarantee opportunities that allow students time "to play and learn from one another, in both formal and informal ways, and time to create, to perform, to argue, to wonder, to appreciate" (Upitis, 2012:695).

This article adopted a qualitative research design from an interpretative theoretical paradigm. I discuss current issues that undergraduate music educators should consider in structuring a music programme. These issues will prepare music students to manage the demands of life and their future working environments. During my thirty years' experience as a music educator my teaching approach changed from teaching knowledge and skills towards putting into practice a philosophy of developing musicians and music teachers who "flourish" as well-rounded individuals. This holistic approach requires an environment of interrelationship where the skills and abilities of a person are acknowledged. These interrelationships are complemented by the wider context of society (community and culture), student participation with educators, working with peers in the classroom, and engaging with the world and universe outside of the classroom (McNickle, 2014:27). "Both people and the world they inhabit are larger than the sum of their parts and it is the incarnation of this perspective into lived reality which holistic education sees as its primary purpose" (Taggart, 2001:326-327). As part of this "think piece"2 (Merriam, n.d.; Merriam, 2016:89), I discuss the following views, supported by appropriate research literature, and my current teaching philosophy: 21st-century skills that can strengthen learning programmes to support living and lifelong learning skills; relationships with oneself, others, God, the universe and the world outside of the classroom, which are maintained by finding your wellbeing through flow and mindfulness; meaningfulness that intensifies social wellbeing and connects one to a culture; spiritual experiences through music in teaching and learning that are life enhancing and represent a subjective understanding of a purposeful life.

1 Thank you to June Boyce-Tillman who introduced this song to me. Words available on http:// biblicalworldviewministries.com/training/fun/givemeaglory.pdf. Thank you also to Prof Hetta Potgieter, who initiated this article.

2 A "think piece" is an academic article in which the researcher discusses a specific concern in a thoughtful way that is tied to personal opinion and background research material (Merriam, 2012). 


\section{Challenges for $\mathbf{2} \mathbf{1}^{\text {st }}$-century graduates}

Music students of the 21st century need specific competencies and attributes to prosper and survive in a world and a time that are constantly changing and developing. Students' success in meeting life's demands depends on their ability to adapt to new situations and environments. To deal with the requirements of today's workplace, music graduates should demonstrate 21 st-century skills that reflect advanced higher-order thinking skills and cognitive developments (Greiff, Niepel \& Wüstenberg, 2015:1). Researchers, business leaders and education specialists are collaborating to develop structures to support life and career skills that outline 21st-century learning outcomes such as information and communication technology (ICT) literacy, creativity, critical thinking and problem solving. These role-players place much emphasis on defining the skills and knowledge that are needed for lifelong learning (Kaufman, 2013:78; Watanabe-Crocket, 2016).

ICT literacy is one of the primary skills that teachers and students should incorporate into their teaching and learning. Digital media have introduced innovation in learning technologies, while online learning has expanded teaching and learning experiences (Liaw, Huang \& Chen, 2007:1066; Paechter \& Maier, 2010:292). Higher education should offer students a combination of technology, pedagogy and classroom design in a technologyrich environment (Long, 2005:60). Hung (2010:281-287) strongly advises that educators take accountability to plan their learning and teaching sessions in the light of the most relevant instructional approaches and technologies available.

Standards of 21st-century skills for career development and creating prospects for individual achievement have been investigated by educational reformers such as P21 Partnership, ${ }^{3}$ Organisation for Economic Co-operation and Development (OECD), ${ }^{4} \mathrm{New}$ Zealand Ministry of Education, ${ }^{5}$ International Baccalaureate ${ }^{6}$ and the Global Digital Citizen Foundation7 (Kaufman, 2013:78; Watanabe-Crocket, 2016). Learning programmes should be structured to develop the capabilities for living and lifelong learning, and to develop fundamental cognitive, affective, personal and social skills. These competencies generate standards that will prepare today's students for commencing their careers. WatanabeCrockett (2015) argues that these standards should include learning that prepares learners to be inquirers, thinkers, risk-takers, etc. (International Baccalaureate) and also include developing the capabilities for living and lifelong learning (The New Zealand Ministry of Education) (see Figure 1). The outcome of learning should communicate transparency-level skills as indicated by Crockett, Jukes and Churches (2011). Kaufman (2013:78-83) also noted comparable attributes in a framework for developing 21 st-century skills instruction. Figure 1 is a representation of these 21 st-century capabilities for living and lifelong learning.

3 P21, The Partnership for 21st Century Learning (formerly the Partnership for 21st Century Skills) was founded in 2002 as an alliance bringing together the business community, education leaders and policymakers to position 21st-century readiness at the centre of United States K-12 education and to kick-start a national conversation on the importance of acquiring 21st-century skills for all students (http://www.p21.org/about-us/our-history).

The mission of the Organisation for Economic Co-operation and Development (OECD) is to promote policies that will improve the economic and social wellbeing of people around the world (http://www.oecd.org/about/).

5 http://nzcurriculum.tki.org.nz/Key-competencies.

6 The International Baccalaureate ${ }^{\circledR}(\mathrm{IB})$ is a non-profit educational foundation offering four highly respected programmes of international education that develop the intellectual, personal, emotional and social skills needed to live, learn and work in a rapidly globalising world (http:// www.ibo.org/about-the-ib/).

7 The Global Digital Citizen Foundation is a non-profit organization dedicated to cultivating responsible, ethical, global citizens for a digital world (https://globaldigitalcitizen.org/vision). 


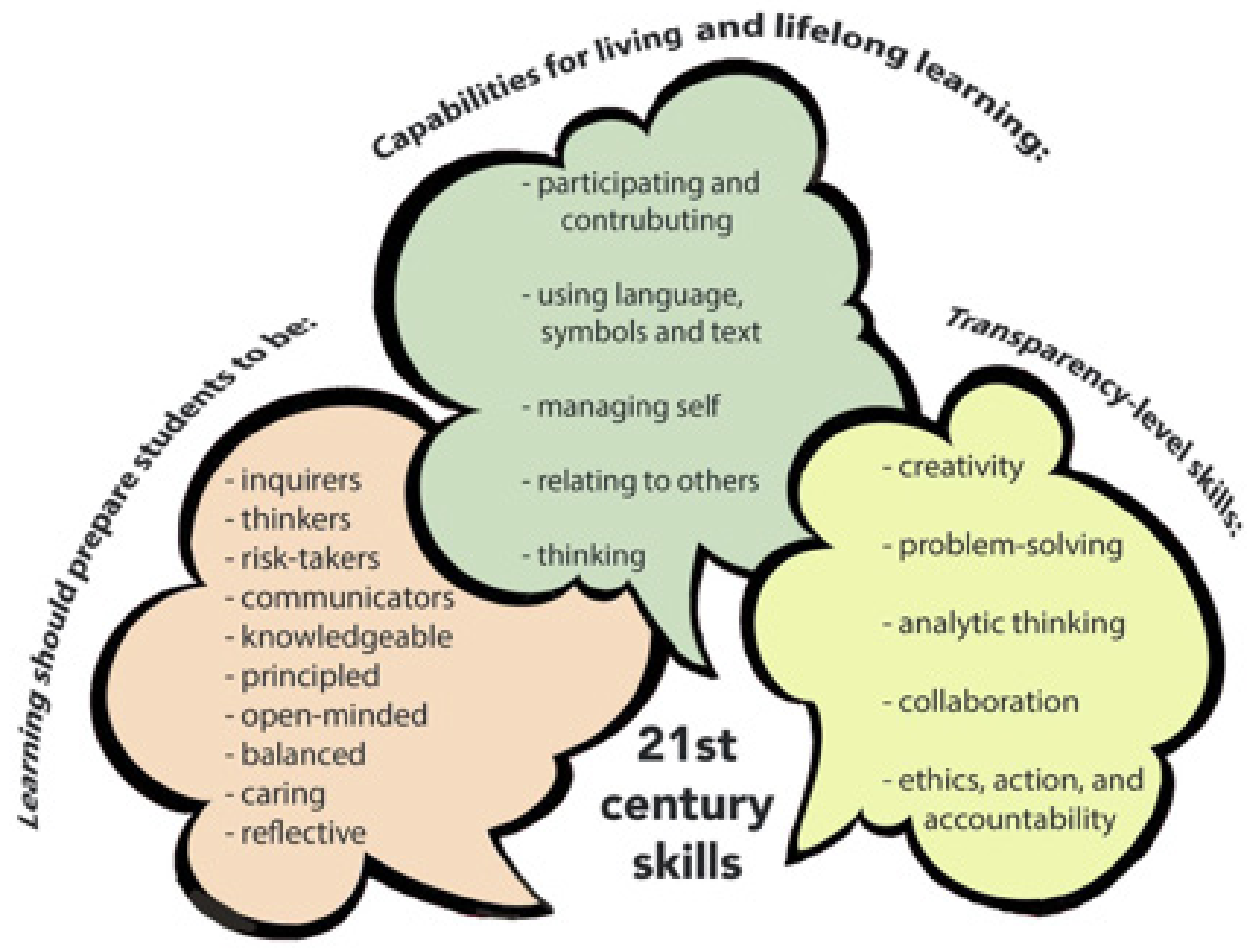

Figure 1: A conceptual diagram of skills for the $\mathbf{2 1}^{\text {st }}$-century learner

Skills for career development and individual achievement are mostly investigated with the global digital citizen in mind. However, these skills are also relevant in the music workplace. The development of transparency-level skills (e.g. problem solving, creativity, analytical thinking, collaboration and accountability) should be integrated purposefully into fundamental content areas of music programmes to motivate learning. Transparencylevel skills cultivate problem solvers who can work self-sufficiently in a music environment where they can demonstrate their distinctive creativity. Inquisitive learners will challenge themselves to solve problems as they arise to generate effective results. Analytical thinking represents the cognitive domain and focuses on higher forms of thinking such as evaluating musical concepts and processes using a creative approach. The sharing of ideas, skills and strengths through teamwork in the musical workplace is encouraged to achieve a common goal. Collaboration depends on communication and individuals must understand that accountable communication represents their values, ideals and beliefs.

Kaufman (2013:79) states that expertise in the workplace is based on developing knowledge and skills related to ethics, accountability, people skills, self-direction and citizenship. "A well-rounded and responsible global digital citizen" (Watanabe-Crocket, 2016) is supportive, unselfish and thoughtful. The cultures and principles of others should be mutually respected to communicate and interact effectively in online and face-to-face environments. Music graduates should embrace the possibilities of education through technology and digital media, but their focus should also be on performing, creating and listening that "involve personal and social-sonic (corporeal, visual, tactile, etc.) actions and events, interpersonal engagements, personal and collective emotions, and the relationships of all of these to the individual circumstances and needs of persons living with and for other persons" (Elliott \& Silverman 2014:58, 59).

Cutler (2010:4) explains that the music world needs

... creative artists who understand current realities and are brave enough to experiment with new solutions. There are opportunities waiting to be discovered by performers who bring great music to new settings, educators who instil its transcendent and spiritual values to students. And administrators who foster new 
audiences while insisting that artistic integrity remain high. There is a shortage of music leaders unveiling new models for success, and artist-citizens leading the crusade to keep meaningful music experiences vibrant.

The teaching environment in South Africa poses unique challenges and the 21st-century skills mentioned above are not the only criteria to give meaning in the work place. Teaching music through an ethical approach creates harmony in the development of students as individuals and encourages them to get involved in creating and sharing music to transform their personal as well as their community's wellbeing. Flourishing, wellbeing and spirituality add that important dimension to accompany students on their journey into the future.

As students who still operate within the borders of their educational environment, they might be anxious of what the future holds. Music educators should cherish their students' strengths and potential, thereby encouraging these learners' 'positive personal self', 'positive social self' and their 'spiritual self' to optimally experience human flourishing in a challenging world (McEntee, 2013:154).

\section{The importance of wellbeing}

More and more individuals, philosophers, education specialists, national governments and civil society organisations are concerned about the overall wellbeing of people. We are constantly evaluating the quality of life, seeking happiness and fulfilment, and looking for ways to improve our physical and emotional wellbeing. Human wellbeing encompasses both health and quality of life, and relates to how humans interact within their physical, social, cultural, emotional and intellectual circumstances and activities in everyday life (Deci \& Ryan, 2008:2; Ryff \& Singer 1998:1-29; Ryff \& Singer 2008:13-39; Sarvimäki, 2006:4-10; Wissing, Potgieter, Guse, Khumalo \& Nel, 2014:5).

Two separate perspectives should always be kept in mind in trying to understand wellbeing. The hedonic or 'feeling good' perspective describes a person's enjoyment, pleasure or focus on happiness and the absence of adverse influences. The eudaimonic perspective or 'functioning well' focuses on living life in a deeply satisfying way. Current research on the concept of eudaimonia concentrates on the search for meaning in life, the realisation of an individual's potential, the search for and achievement of meaningful goals, personal growth, making a difference and flourishing. 'Functioning well' also embodies flourishing even in difficult times (Deci \& Ryan, 2008: 1-11; Elliott \& Silverman, 2015:142,143; Reker, 2011:1; Wissing et al., 2014:2,8; Wong, 2011:70;).

Wissing et al. discuss the most prominent constructs of eudaimonic well-being. Authenticity, meaning and purpose, personal growth and self-realisation, vitality and a zest for life, time perspective, goals, intrinsic motivation and flow, self-regulation, mindfulness, constructive coping and post-traumatic growth are all constructs and processes associated with a "life well lived" (2014:44-62). For the purpose of this article I discuss two of these core concepts that can add to a music student's awareness of flourishing while they are engaged in the processes of creating, performing and listening: experiencing flow and mindfulness.

Csikszentmihalyi (2014) first proposed flow theory (Beard, 2014:353) and has studied it for over four decades; he defines flow as the overall awareness of joy and pleasure that people experience when they are fully involved in a process. Flow may be experienced as enjoyment, focus, absorption and intrinsic motivation during a number of activities and tasks, including reading, listening to music, involvement in creative activities, sport and even work (Nakamura \& Csikszentmihalyi, 2009:196; Wissing, 2014:56). Flow experiences differ from everyday life experiences and are beyond an individual's conscious control (Bernard, 2009:6, 11). Flow is in fact a subconscious occurrence which is connected with elevated performance and positive experiences (Fritz \& Avsec, 2007:5). When people's attention is 
completely absorbed in the challenges at hand, they achieve a state of consciousness in which their thoughts, feelings, wishes and action are in harmony in a rich, complex way. Flow theory is "informative and instructive" and can therefore be valuable when educators experience a lack of commitment from students and want to boost them to recognise their personal accomplishments (Beard, 2015:353,363; Bernard, 2009:6). Fritz and Avsec (2007:5) studied the relation of experiencing flow during different musical activities to subjective wellbeing in life in general. Their research shows that flow is more related to emotional than cognitive aspects of subjective wellbeing. During the praxis of creating or performing a musical artwork, musicians should be aware of the experience of enjoyment. It is the honourable 'calling' of music educators to introduce the awareness of experiencing flow (an experience of enjoyment) to their students. Frequent engagements in flow experiences contribute to an individual's happiness and the development of greater personal harmony between "goals and desires, sensations and experiences, both for oneself and for others" (Bernard, 2009:7). Custodero (2002: 6-8) stipulates important principles that influence optimal experiences of flow in music education. The educator should provide pertinent challenges to learners to motivate learning. As independent learners, students transform musical activities into experiences that are personally meaningful. The educator should design musical activities that incorporate authenticity (features from students' own lifeworlds and culture) and draw on their strengths.

Mindfulness (the focus on, or being conscious and aware of, the present moment) and education are interconnected. "When teachers are fully present, they teach better. When students are fully present, the quality of their learning is better" (Schoeberlein \& Sheth, 2009:xi). Mindfulness helps educators to focus on the enjoyment and satisfaction of their careers, because they can appreciate their creativity and focus their thoughts on the constructive management of stress and emotions. Implementation of student-centred teaching and learning approaches - such as problem-based learning and social constructivism - will increase analytical and creative thinking in their students and encourage independent learning. Mindfulness may lead to students becoming more focused, eager to learn and better motivated to achieve academic success. "Tapping into the potential of mindfulness begins when teachers and students learn to pay attention to the experience of paying attention" (Hyland, 2015:179; Schoeberlein \& Sheth, 2009:xii). Music educators need to give students opportunities to become mindful about music as a discipline. It is necessary to share ideas and discuss how they explore music through 'thinking'. Music becomes the "exploration of thinking" (Benedict \& Schmidt, 2015:17).

Meaningfulness is also linked to a person's cultural identity (Baumeister, Vohs, Aaker \& Garbinsky, 2013:506). However, people all over the world are gradually being influenced by aspects from different cultural worlds. We make individual choices from the universal cultural 'display' that envelops us to find options that benefit our personalities and particular ambience and aspirations. South Africa is a multi-cultural society (Potgieter, 2017:19) and the process through which cultures merge as a result of continued interaction contributes to eudaimonic and hedonic wellbeing. This process is called acculturation: when individuals with different kinds of cultural upbringing meet, it is possible that they will embrace one another's languages, morals, conduct, communal associations and technologies (Sam \& Berry, 2010:472). Wellbeing and happiness cannot be consistently measured in all cultures, because people have their own individual expectations of happiness and may react differently to situations. Happiness is also grounded in diverse understandings of what a meaningful life entails (Diener \& Suh, 1997:199; Mathews, 2012:303; Wissing et al., 2014:265-279).

Wissing et al. explain (2014:265) that people's relationship to life's purpose and beliefs, as well as to music and art, is influenced by the culture in which they are embedded. In my view, it is the educator's responsibility to understand what the students' cultural norms or community orientations are, and what kind of musical experiences they need to participate in 'life'. We need to determine what the students' strengths are that have been developed 
through their culture and consequently how they can contribute towards making a difference to life-long engagement through music in South African communities. Music programmes can incorporate students' life skills that were shaped by the individual cultural experiences that shaped their wellbeing.

Through education, students can be nurtured to live their lives with hope, truth, respect, wisdom and wellbeing (Smith, 2015). Students can flourish in life when "received wisdom" is passed on (Boyce-Tillman, 2000:89) and learners get the opportunity to unite with others to build relationships and environments for learning (Smith, 2015). Music plays a role in the understanding of life as a means to experience wellbeing (Boyce-Tillman, 2000:89; Freeman, 2003). Allsup (2012:171-178) aims to redirect current practices in music education to focus on human flourishing. He pleads for music education to become "human and not merely musical" (2012:177). Learners should develop social skills that expand their personal competence to engage with and help others on their emerging paths. Education must encourage a life of thought, but it must also be practical and focused on creating a "musical human" (2012:176). He suggests establishing an environment that is democratic, where the educator is prepared to teach within the frameworks of long ago, the now, and the future. A music programme that embraces aspects of 'functioning well' can change the way students approach their studies and how they will in future succeed in work, life and accountability in 21 st-century society.

Educative and ethical music teaching and music making balances the care, growth, and positive transformation of students as persons with teaching strategies and conditions that foster artistry. Thus, in addition to being informed about students' musical and educational needs and desires, music educators at all levels of instruction (elementary, secondary, tertiary) should be mindful of each student's multidimensional personhood - artistic, emotional, cognitive, social, cultural, and personal (Elliot \& Silverman, 2014:58).

\section{Searching for meaning in life through spirituality}

Spirituality "tends to refer simply to the process of human maturation" (Sheldrake, 2011:6). People in Western cultures continue to search for meaning in life and seeking answers in their spiritual pursuits (Morgan \& Boyce-Tillman, 2016:153). Jordaan (2011:190) describes spirituality as manifesting when ordinary experiences cause the 'soul to shine'. When our souls 'open up' to extraordinary focal points we encounter spiritual experiences and find the essence, meaning and purpose of living through nature, human relationships or a Supreme Being. Spirituality communicates our sincerest incentives when we are acting in the "right spirit" (Taggart, 2001:325).

Spirituality consists not only of implicit assumptions about life but also of the things people talk about and the things they do; the stories they construct about their spiritual journeys, the prayers they offer, the inspirational books they read, the time they spend meditating, their participation in retreats and at worship services, the conversations they have about it with their friends, and the energy they spend thinking about it ... But spirituality is not just the creation of individuals; it is shaped by larger social circumstances and by beliefs and values in the wider culture (Wuthnow,1998:156).

Irwin (2006:75) explains that everyday life experiences form links to an "aesthetic and spiritual pedagogy of self". The music curriculum should allow students to engage in creative activities that result in an ongoing questioning and involvement with beliefs as time goes on. Students will then have the freedom to envisage, recognise and be present in the moment as they allow themselves to engage with the world aesthetically and spiritually (Irwin, 2006:78). Music educators who are perceptive and understanding often realize that 
students are investigators of the spiritual realm. To inspire music educators to focus on the connections between learning music and spirituality, more research is being done in psychology and education. Boyce-Tillman (2014:27) refers to the paper presented by Heuser (2012:116), who states that music educators need to encourage learners' natural competence "for creating meanings". This enables individuals to invest their energy in the present, sympathize with others, and "experience private moments of awe, wonder and transcendence" (Boyce-Tillman, 2014:27).

Throughout the history of Western music spirituality and music have been associated with each other. In many civilizations music was connected to the sacred and the spiritual. In his Politica, Book VIII, Aristotle claimed that "the songs of Olympus exercise" inspired enthusiasm as an emotion of the ethical part of the soul (Ryan, Curren \& Deci, 2013:57-69). Martin Luther (1483-1546) believed that the spiritual world of people improved through musical performance (Campbell, 2008:21, 24). Nelson Mandela (1918-2013) made a surprise appearance on stage with Johnny Clegg in Frankfurt in 1999, where he proclaimed: "It is music and dancing that makes me at peace with the world ... and at peace with myself". ${ }^{8}$

Boyce-Tillman (2007:1405) examines the different ways in which people experience spirituality in music by approaching music through the experience of the experiencer. She focuses on a conceptual framework (Figure 2) which explains the overlapping of four domains, which results in an experience of spirituality through music. The experience starts with a depth of feeling in one of the domains which progressively spreads to embrace them all. Disruptions in one or between two domains will affect the total experience and the Spiritual domain cannot emerge.

\section{The Spiritual Experience in Music}

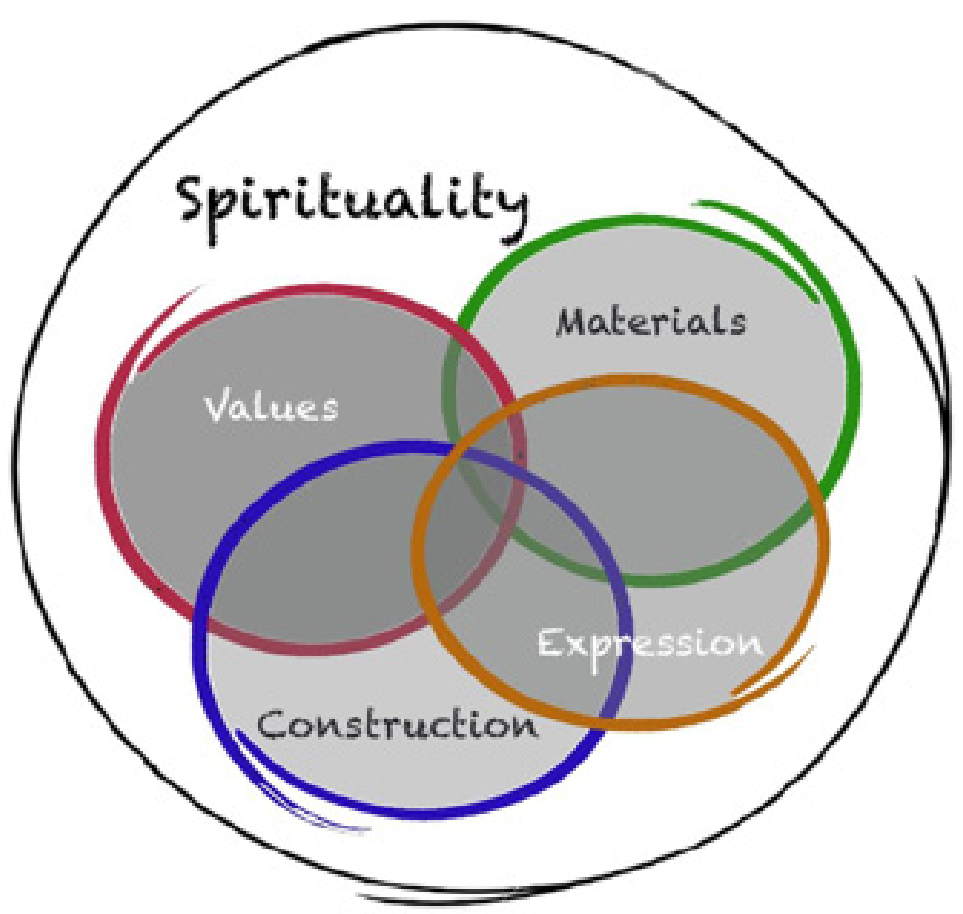

Figure 2: Model for spiritual experience in music (Boyce-Tillman, 2014:26)

The four domains are (Boyce-Tillman, 2007:1408-1410): 
- Expression

This domain includes expressing "mood", "emotion", "images", "memories" and "atmosphere" (Boyce-Tillman, 2007:1409) as individuals or through shared experiences in a group. When the individual 'feels' the music, the experiences can be intrinsic, evoking qualities such as nostalgia, tenderness, vulnerability, pleasure, enthusiasm (Boyce-Tillman, 2013:54). The listener can also add an extrinsic connotation to the music made by the performer.

- Materials

Who is singing and what the instrument is made of (sounds of instruments/voices as the basis of musical skills) focus the listening experience on recognition of the breadth of the space in which the musical activity is taking place. In the spiritual experience these concrete elements are bound together in their complexity within the physical world. The music becomes a "form of embodied cognition" (Boyce-Tillman, 2013:54). When the performer or composer experiences the Spiritual domain, their bodies form a 'relationship' of familiarity and closeness with the material from which the instrument is made.

- Construction

In this domain the organisation of musical dimensions such as repetition, contrast and the thematic structure of the work can unexpectedly create a spiritual environment. Construction can also be connected to experiencing a culture's non-verbal concepts and impressions. In the $17^{\text {th }}$ century black American slaves embraced and modified notated Western music composition traditions to create the wonderful sounds of gospel to express their spirituality (Boyce-Tillman, 2013:55).

- Value:

Values of a culture can be emulated in its music. The environment of the music-making experience in relation to the understanding of culture and society relate to this domain. The original context, the context in which the music is performed and the reason for the performance connects with the other three domains to merge into a spiritual experience (Boyce-Tillman, 2013:56).

Despite trends in teaching programmes and the structuring of curricula toward regulations and administration, there is a universal yearning for focus on the spiritual in education. "An education of the soul is an education filled with feeling completely alive, being at one with the universe while experiencing joy, compassion, mindfulness and a sense of awe for the mystery that abounds" (Irwin, 2007:1401). A music curriculum that give space for students to be mindful and experience spirituality delivers students who centre their thinking on an essential understanding of life. They will ask meaningful questions and will ultimately form their own beliefs to flourish in life.

\section{End result for undergraduate education in music}

I am advocating an undergraduate music teaching and learning practice that will reach an observable end result (goal) of students who are prepared to be engaged in lifelong, real-life problem-solving situations that are holistic in nature. Students need to engage in authentic activities that involve direct contact with the subject matter to be learned, and to construct their own understanding throughout the encounter of their engagement (Wiggins, 2015:19, 20). Holistic practices include the affective, cognitive and spiritual domains of learning and use a combined philosophy that prepares students to think logically to participate in critical thinking, as well as embracing emotion and using their creativity.

To complement the holistic curriculum, the pragmatic approach by the American philosopher and educational reformer Dewey (1859-1952) explains that the teaching and learning process can become an experience of embodiment. Through Dewey's action- 
based pragmatism, where students are involved 'through the mind' in all art forms (visual arts, dance and drama), they participate in experiences as individuals and become who they are by virtue of social interaction in their culture (Dewey 1934:326). The expressive communication between individuals and their surroundings and the totality of an experience involves flow and mindfulness. Dewey's holistic aesthetic education conveys the notion that mind signifies the "situated individual first-person" (Westerlund 2003:47) who perceives the world through meanings. Meaning, according to Dewey, is not a mental process but an attitude that cooperates with the social environment.

Hence, generally speaking, the meaning of a particular piece of music is the sense it makes. This "sense" is not a question of subjective feelings, inward cognition, or skills in relation to the object, but very much a cultural, contextual, and public matter that can be discussed, learned, tried out, and enjoyed by focusing consciousness on different aspects that are involved in meaning-making (Westerlund 2003:47).

Dewey also did not classify music as 'high art'. Music is a field of art that involves all people's approaches to their cultural lives and everyday experiences. Aesthetics originates from experiencing ordinary life activities (Westerlund, 2003:49, 60) in a positive way. These experiences should be integrated in praxis, are shared with others and make a qualitative difference in education. Dewey explained that art is aesthetic through the combination of the doing, feeling and thinking in a musical experience (Westerlund, 2003:50). Pragmatist aesthetics understands "the world of art by starting to understand the world of everyday experience" (Stroud, 2014:34). Bogdan (2003:92) suggests that "educational practice and theory need to reinforce acknowledgement of the classroom as a site for learning and teaching from a position of vulnerability, for the dialectic between loss and reparation felt at the level of the body in what I would call a pedagogy of ordinary existence."

My personal teaching philosophy is influenced by Barell (2010), Barrett (2005), Luckett (2001) and Wiggins (2015) and involves a teaching and learning environment that establishes meaningful, lifelong experiences. Barell (2010:177) encourages problem-based learning as a teaching and learning method to provide students with techniques to be problem solvers. A music curriculum that focuses on excellence uses various didactic approaches to allow time to reflect on music and its usefulness for students and teachers. Such a curriculum promotes analytical thinking, features individual, small and large group settings to encourage independence, and offers ample opportunities for discovering various musics in university and different community environments (Barrett, 2005:23). Luckett (2001:49) initiates the "four ways of knowing and learning" to develop tertiary curricula: cognitive learning, learning by doing to apply knowledge, experiential learning; and the ability to think reflectively and contextually about what was learned. From Wiggins (2015) I learned that learning music is an embodied, constructive process. We construct understanding from experiences through participating in the interactive musical practices of creating, performing and listening. As educators we need to enable our students to learn with "musical understanding" so as to encourage proficient and ultimately musically independent musicians (Wiggins, 2015:2740).

As a music educator teaching music education as a subject, I am inclined to prepare music students through engagement in real-life musical problem-solving experiences to motivate them towards achieving an outcome of finding "their own teaching path" (Cruywagen, 2015:55). This outcome focuses on a meaningful understanding of how to teach to establish learning and create significant, lifelong practice. Music students are equipped to bring together their musical knowledge and personal development as musicians and their understanding of the teaching and learning process using a musical cognitive approach. 


\section{Coda}

Figure 3 represents the music students who can become inspired 21 st-century citizens who enjoy their work, share their talents and skills with others, and make a difference in their own lives as well as in their communities that so desperately need wellbeing and spiritual growth. They will be able to change their environments with their creations and performances, and people will appreciate their eudaimonia.

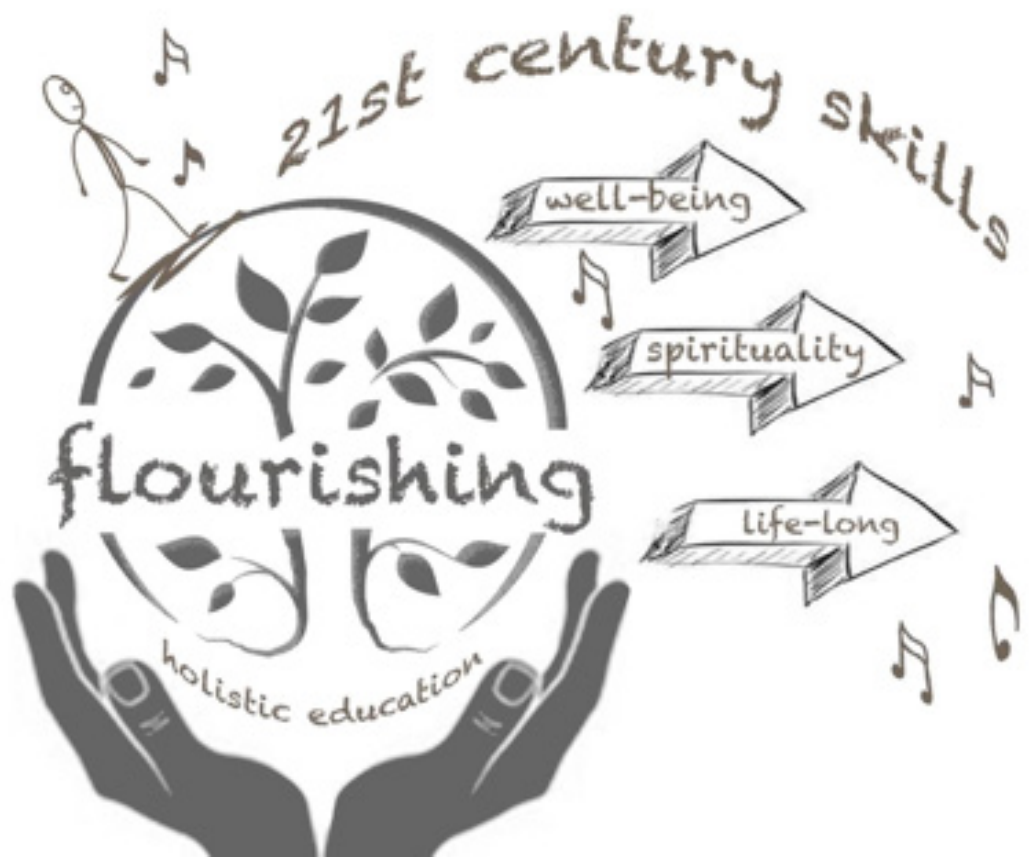

Figure 3: Flourishing with music: approaches to prepare undergraduate music students to find their own wellbeing in life.

This article investigates a few important perspectives that will lay the groundwork for undergraduate music educators to structure a music programme that prepares music students to cope with the demands of being the music leaders of tomorrow. On the music students' journey to becoming well-rounded and responsible people, their individual personal musical understanding formed through diverse lived musical experiences can be used by the music educator as the point of departure. A focal point for creating the tertiary music programme should be the destination of lifelong engagement in music, musical experiences outside of university and finding their own path to take them into the professional world of music.

To conclude this research article, a poem by Elizabeth Bishop summarises the argument I want to emphasise ... focus on the quality of the experience, appreciate a moment of happiness, meaning, and reawakening and give oneself time to 'flourish'. 


\section{I am in Need of Music ${ }^{9}$}

I am in need of music that would flow

Over my fretful, feeling fingertips,

Over my bitter-tainted, trembling lips,

With melody, deep, clear, and liquid-slow.

Oh, for the healing swaying, old and low,

Of some song sung to rest the tired dead,

A song to fall like water on my head,

And over quivering limbs, dream flushed to glow!

There is a magic made by melody:

A spell of rest, and quiet breath, and cool

Heart, that sinks through fading colors deep

To the subaqueous stillness of the sea,

And floats forever in a moon-green pool,

Held in the arms of rhythm and of sleep.

Elizabeth Bishop 


\section{Reference list}

Allsup, R.E. 2012. Music education and human flourishing: a meditation on democratic origins. British journal of music education, 29(2):171-179. Doi: https://doi.org/10.1017/S0265051712000034

Barell, J. 2010. Problem-based learning: the foundation for 21st century skills. (In Bellanca, J.A. ed. 21st century skills: Rethinking how students learn. Bloomington: Solution Tree Press. p.175-199).

Barrett, J.R. 2005. Planning for understanding: a reconceptualised view of the music curriculum. Music Educators Journal, 91(4):21-25.

Baumeister, R.F., Vohs, K.D., Aaker, J.L. \& Garbinsky, E.N. 2013. Some key differences between a happy life and a meaningful life. The journal of positive psychology, 8(6):505-516. Doi: https://doi.org/10.108 $\underline{0} / 17439760.2013 .830764$

Beard, K. 2015. Theoretically speaking: an interview with Mihaly Csikszentmihalyi on flow theory development and its usefulness in addressing contemporary challenges in education. Educational Psychology Review, 27(2):353-364. Doi: https://doi.org/10.1007/s10648-014-9291-1

Benedict, C. \& Schmidt, P. 2015. Acts of courage: leaping into mindful music teaching. Canadian Music Educator, 56(3):16-20.

Bernard, R. 2009. Music making, transcendence, flow, and music education. International Journal of Education \& the Arts, 10(14):1-21.

Bogdan, D. 2003. Musical spirituality: reflections on identity and ethics of embodied aesthetic experience in/and the academy. Journal of aesthetic education, 37(2):80-98. Doi: https://doi.org/ 10.1353/jae.2003.0011

Boyce-Tillman, J. 2000. Promoting well-being through music education. Philosophy of Music Education Review, 8(2):89-98

Boyce-Tillman, J. 2007. Spirituality in the musical experience. (In Bresler, L., ed. International handbook of research in arts education. New York: Springer. p. 1405-1422). Doi: https://doi.org/ 10.1007/9781-4020-3052-9 96

Boyce-Tillman, J. 2013. Music \& well-being-music as integrative experience. Journal of Urban Culture Research, 7:48-71.

Boyce-Tillman, J. 2014. Music and well-being. TD: The journal for transdisciplinary research in Southern Africa: Special edition: music and well-being, 10(2):12-33. Doi: https://doi.org/10.4102/td.v10i2.96

Campbell, P.S. 2008. Musician \& teacher. An orientation to music education. New York: W.W Norton \& Company.

Crockett, L., Jukes, I. \& Churches, A. 2011. Literacy is not enough. 21st-century fluencies for the digital age. 21st Century Fluency Project Inc. California: Corwin Press.

Cruywagen, S. 2015. "Blending with purpose": a multimodal model for Music Education. Thesis submitted for the degree Doctor Philosophiae in Music. Potchefstroom: NWU. (Thesis - PhD)

Csikszentmihalyi, M. 2014. Flow and the foundations of positive psychology: the collected works of Mihaly Csikszentmihalyi. Dordrecht: Springer. Doi: https://doi.org/10.1007/978-94-017-9088-8_17

Custodero, L.A. 2002. Seeking challenge, finding skill: Flow experience and music education. Arts Education Policy Review, 103(3):3-9. Doi: https://doi.org/10.1080/10632910209600288

Cutler, D., 2010. The savvy musician: building a career, earning a living, \& making a difference. Pittsburgh: Helius Press.

Deci, E.L. \& Ryan, R.M. 2008. Hedonia, eudaimonia, and well-being: an introduction. Journal of happiness studies, 9(1):1-11. Doi: https://doi.org/10.1007/s10902-006-9018-1

Dewey, J. 1934. Art as experience. New York: Perigee Books.

Diener, E. \& Suh, E. 1997. Measuring quality of life: economic, social, and subjective indicators. Social indicators research, 40(1-2):189-216. Doi: https://doi.org/10.1023/A:1006859511756

Elliott, D.J. \& Silverman, M. 2014. Music, personhood and eudaimonia: implications for educative and ethical music education. The journal for transdisciplinary research in Southern Africa, special edition, 10(2):57-72. Doi: https://doi.org/10.4102/td.v10i2.99

Elliott, D.J. \& Silverman, M. 2015. Music matters: a philosophy of music education. New York: Oxford University Press.

Fritz, B.S. \& Avsec, A. 2007. The experience of flow and subjective well-being of music students. 
Horizons of Psychology, 16(2):5-17.

Greiff, S., Niepel, C. \& Wüstenberg, S. 2015. 21st century skills: International advancements and recent developments. Thinking Skills and Creativity, (18):1-3. Doi: https://doi.org/10.1016/ j.tsc.2015.04.007

Heuser, F. 2012. Secular Spirituality in the Music Classroom. (Paper presented at Musical Paedia, International Society for Music Education Conference, Thessaloniki, Greece, July 2012, p. 116-117.)

Hung, D. 2010. Theories of learning and computer-mediated instructional technologies. Educational Media International, 38 (4):281-287. Doi: https://doi.org/10.1080/0952398 0110105114

Hyland, T. 2015. On the contemporary applications of mindfulness: some implications for education. Journal of philosophy of education, 49(2):170-186. Doi: https://doi.org/10.1111/1467-9752.12135

Irwin, R.L. 2006. Walking to create an aesthetic and spiritual currere. Visual Arts Research, 32(62):75-82.

Irwin, R.L. 2007. "Plumbing the depths of being fully alive." (In Bresler, L., ed. International handbook of research in arts education. Dordrecht: Springer. p. 1401-1404.) Doi: https://doi.org/ 10.1007/9781-4020-3052-9 95

Jordaan, W. 2011. Spitstyd: uitgesoekte rubrieke. Pretoria: Litera Publikasies.

Kaufman, K.J. 2013. 21 Ways to 21st Century Skills: Why students need them and ideas for practical implementation. Kappa Delta Pi Record, 49(2):78-83. Doi: https://doi.org/10.1080/ 00228958.2013 .786594

Liaw, S.S. Huang, H.M. \& Chen, G.D. 2007. Surveying instructor and learner attitudes toward e-learning. Computers \& Education, 49 (4):1066-1080. Doi: https://doi.org/10.1016/j.compedu .2006.01.001

Long, P.D. 2005. Learning space design in action. Educause review, 40 (4):60.

Luckett, K. 2001. Responding to equity and development imperatives: conceptualizing a structurally and epistemically diverse undergraduate curriculum in postDapartheid South Africa. Equity \& Excellence in Education, 34(4):26-35. Doi: https://doi.org/10.1080/1066568010340304

Mathews, G. 2012. Happiness, culture, and context. International journal of wellbeing, 2(4):299-312.

McNickle, C.P. 2014. Approaching a more holistic education. Thesis submitted for the degree Doctor Philosophiae. Greensboro: University of North Carolina. (Thesis - PhD)

Merriam, S.B. n.d. Writing for publication: four types of articles. Paper presented at NWU Postgraduate Music Education Workshop, Potchefstroom, May 2012.

Merriam, S.B. 2016. Qualitative Research. A guide to design and implementation. San Francisco: Jossey-Bass.

Morgan, S. \& Boyce-Tillman, J. 2016. A River Rather Than a Road: The Community Choir as Spiritual Experience. Oxford: Peter Lang.

Nakamura, J. and Csikszentmihalyi, M. 2009. Flow theory and research. (In Snyder, C.R. \& Lopez, S.J. eds. Oxford Handbook of positive psychology, p.195-206. Oxford: Oxford University Press.)

Paechter, M. \& Maier, B. 2010. Online or face-to-face? Students' experiences and preferences in e-learning. Internet and higher education, 13:292-297. Doi: https://doi.org/10.1016/j.iheduc .2010 .09 .004

Partnership for 21st Century Skills. 2011. Framework for 21st century learning. http://www.p21. org/index.php?option=com_content\&task=view\&id=254\&ltemid=120Silva,\%20E.\%20(2008).\%20 Measuring\%20skills\%20for\%20the\%2021st\%20century.\%20Washington Date of access: 5 Nov. 2016.

Potgieter, H.M. 2017. "The cathedral without a roof": a metaphorical search for meaning. (In BoyceTillman, J. (Ed). Spirituality and Music Education: Perspectives from Three Continents, Oxford: Peter Lang (In print).

Reker, G.T. \& Woo, L.C. 2011. Personal meaning orientations and psychosocial adaptation in older adults. Sage open: 2011(1):1-10. Doi: https://doi.org/10.1177/2158244011405217

Ryan, R.M. Curren, R.R. \& Deci, E.L. 2013. What humans need: Flourishing in Aristotelian philosophy and self-determination theory. (In Waterman, A.S. ed. The best within us. Washington: American Psychological Association. p. 57-75.) Doi: https://doi.org/10.1037/14092-004

Ryff, C.D. \& Singer, B. 1998. The contours of positive human health. Psychological inquiry, 9(1):1-28.

Ryff, C.D. \& Singer, B.H. 2008. Know thyself and become what you are: A eudaimonic approach to psychological well-being. Journal of happiness studies, 9(1):13-39. Doi: https://doi.org/ 10.1007/ 


\section{s10902-006-9019-0}

Sam, D.L. \& Berry, J.W. 2010. Acculturation when individuals and groups of different cultural backgrounds meet. Perspectives on psychological science, 5(4):472-481. Doi: https://doi.org/10. $1177 / 1745691610373075$

Sarvimäki, A. 2006. Well-being as being well - a Heideggerian look at well-being. International journal of qualitative studies on health and well-being, 1(1):4-10. Doi: https://doi.org/10.1080/ 17482620500518101

Schoeberlein, D. \& Sheth, S. 2009. Mindful teaching and teaching mindfulness. Boston: Wisdom Publications.

Sheldrake, P. 2011. Spirituality in a European Context. Spiritus: A Journal of Christian Spirituality, 11(1):19. Doi: https://doi.org/10.1353/scs.2011.0020

Smith, M. K. 2015. What is education? A definition and discussion. The encyclopaedia of informal education. http://infed.org/mobi/what-is-education-a-definition-and-discussion/ Date of access: 13 Jan. 2017.

Stroud, S.R. 2014. The art of experience: Dewey on the aesthetic. Practicing pragmatist aesthetics: critical perspectives on literature and the arts. Amsterdam: Rodopi.

Taggart, G. 2001. Nurturing spirituality: A rationale for holistic education. International journal of children's spirituality, 6(3):325-339. Doi: https://doi.org/10.1080/13644360120100496

Upitis, R.B. 2012. Music and the arts: as ubiquitous and fundamental as the air we breathe. (In McPherson, G.E. \& Welch G.F., eds. The Oxford handbook of music education. New York: Oxford University Press. p. 689-693). Doi: https://doi.org/10.1093/oxfordhb/9780199928019.013.0061

Watanabe-Crockett, L. 2016. The critical 21st century skills every students needs and why. Global digital citizen foundation. Date of access: 5 November 2016 from https://globaldigitalcitizen.org/21stcentury-skills-every-student-needs

Westerlund, H. 2003. Reconsidering aesthetic experience in praxial music education. Philosophy of music education review, 11(1):45-62. Doi: https://doi.org/10.1353/pme.2003.0008

Wiggins, J. 2015. Teaching for Musical Understanding. New York: Oxford University Press.

Wissing, M.P., Potgieter, J.C., Guse, T., Khumalo, I. \& Nel, L. 2014. Towards flourishing: contextualizing positive psychology. Van Schaik: South Africa.

Wong, P.T. 2011. Positive psychology 2.0: towards a balanced interactive model of the good life. Canadian psychology/Psychologie Canadienne, 52(2), p.69. Doi: https://doi.org/10.1037/a00 22511

Wuthnow, R. 1998. After heaven: Spirituality in America since the 1950s. Los Angeles: University of California Press. 